\title{
Multivariate study and regression analysis of gluten-free granola
}

\author{
Lilian Maria PAGAMUNICI ${ }^{1,4}$, Aloisio Henrique Pereira de SOUZA ${ }^{1}$, Aline Kirie GOHARA ${ }^{1}$, \\ Alline Aparecida Freitas SILVESTRE ${ }^{1}$, Jesuí Vergílio VISENTAINER ${ }^{2}$, Nilson Evelázio de SOUZA ${ }^{3}$, \\ Sandra Terezinha Marques GOMES², Makoto MATSUSHITA ${ }^{2 *}$
}

\begin{abstract}
This study developed a gluten-free granola and evaluated it during storage with the application of multivariate and regression analysis of the sensory and instrumental parameters. The physicochemical, sensory, and nutritional characteristics of a product containing quinoa, amaranth and linseed were evaluated. The crude protein and lipid contents ranged from 97.49 and $122.72 \mathrm{~g} \mathrm{~kg}^{-1}$ of food, respectively. The polyunsaturated/saturated, and n-6:n-3 fatty acid ratios ranged from 2.82 and 2.59:1, respectively. Granola had the best alpha-linolenic acid content, nutritional indices in the lipid fraction, and mineral content. There were good hygienic and sanitary conditions during storage; probably due to the low water activity of the formulation, which contributed to inhibit microbial growth. The sensory attributes ranged from 'like very much' to 'like slightly', and the regression models were highly fitted and correlated during the storage period. A reduction in the sensory attribute levels and in the product physical stabilisation was verified by principal component analysis. The use of the affective test acceptance and instrumental analysis combined with statistical methods allowed us to obtain promising results about the characteristics of gluten-free granola.
\end{abstract}

Keywords: cereal; pseudo-cereals; food science; principal component analysis; fatty acids.

\section{Introduction}

Gluten-rich foods such as oat, barley, rye, and wheat cause an inflammation of the villi in the small intestine with subsequent villous atrophy and low absorption of nutrients in affected individuals (Fasano et al., 2008). The development of gluten-free foods requires ingredients with high nutritional value such as amaranth, quinoa, and linseed. Amaranth and quinoa have similar compositions, mainly in terms of protein and ash contents (Palombini et al., 2013). High levels of crude fibre and total lipids, 8.3 and $43.9 \%$, respectively, have also been found in linseed (Gutiérrez et al., 2010). Linseed is distinct from the pseudo-cereals due to its lipid fractions of fatty acids, i.e. 14.5-22.2\% (oleic; 18:1 n-9), 15.1-17.4\% (linoleic; 18:2 n-6), and 51.8-60.4\% (alpha-linolenic; 18:3 n-3), while quinoa and amaranth have $0.6-3.8,23.6-26.5$, and $35.3-48.1 \%$ of these fatty acids, respectively (Ryan et al., 2007).

The cultivars Chenopodium quinoa BRS Piabiru and Amaranthus cruentus BRS Alegria have been genetically modified for the central-western Brazil climatic conditions and for saponin removal, which are considered a toxic compound in vivo although efficient insecticides and anti-microbial agents for the plant. The chemical composition of the new cultivars was not modified. This study was conducted by the Brazilian Agricultural Research Corporation - Embrapa Cerrados Center, Brasília, DF, Brazil (EMBRAPA) (Spehar et al., 2002, 2003).

The development of foods rich in essential compounds such as amino acids, minerals, fibres, and fatty acids that are also free of anti-nutritional factors is necessary, particularly due to the dietary restrictions of celiac disease sufferers. Food shelf life is defined as the time period between the packing of a product and its use, during which the product maintains good sensory characteristics and safe microbial parameters that are acceptable for consumption (Loverday et al., 2009). When a product is stored, sensory attributes are highly important for the marketing of the product (Giménez et al., 2012). The sensory perception of changes in food by the consumer is a crucial factor in purchasing decisions. According to Dutcosky et al. (2006), affective tests are a promising tool to obtain information directly from consumers, who already have a sensory memory of the product being assessed.

Another important factor in shelf life testing is the use of statistical models to study and correlate the responses obtained from consumers' perception and/or instrumental tests. Accordingly, linear regression models enable the assessment of each parameter as a function of time. Multivariate analysis enables extracting additional information compared to univariate analysis. Principal component analysis (PCA) is based on performing linear comparisons of the original variables. Principal components (PC) are mutually orthogonal and explain variance decrease with an increase in PC number (Correia \& Ferreira, 2007).

This study aimed to develop a gluten-free granola with high nutritional value and to evaluate it during storage with the application of multivariate and regression analysis using sensory and instrumental parameters. The product was developed using

\footnotetext{
Received 26 Nov., 2013

Accepted 10 Jan., 2014 (006233)

${ }^{1}$ Center of Agricultural Sciences, Department of Chemisty, State University of Maringa, Maringá, PR, Brasil

${ }^{2}$ Department of Chemisty, State University of Maringa, Maringá, PR, Brasil, e-mail: mmakoto@uem.br

${ }^{3}$ Federal Technological University of Parana, Londrina, PR, Brasil

${ }^{4}$ Inga Faculty, Maringá, PR, Brasil

${ }^{*}$ Corresponding author
} 
A. cruentus BRS Alegria and C. quinoa BRS Piabiru as sources of protein and minerals and L. usitiassimum L. as a source of alpha-linolenic acid.

\section{Materials and methods}

\subsection{Sample formulation}

The grains of A. cruentus BRS Alegria and C. quinoa BRS Piabiru used in the development of the granola formulation were provided by EMBRAPA. The other ingredients were purchased from the local market in Maringá, Paraná state. Samples of amaranth and linseed were collected from $60-\mathrm{kg}$ grain bags. Linseed was coarsely ground.

The granola formulation consisted of: a binder phase (syrup) - $150 \mathrm{~g} \mathrm{~kg}^{-1}$ honey, $60 \mathrm{~g} \mathrm{~kg}^{-1}$ brown and refined sugar; $40 \mathrm{~g} \mathrm{~kg}^{-1}$ invert sugar; $30 \mathrm{~g} \mathrm{~kg}^{-1}$ water; $10 \mathrm{~g} \mathrm{~kg}^{-1}$ canola oil; and a solid phase - $160 \mathrm{~g} \mathrm{~kg}^{-1}$ amaranth and quinoa, $90 \mathrm{~g} \mathrm{~kg}^{-1}$ corn flakes, $40 \mathrm{~g} \mathrm{~kg}^{-1}$ rice flakes, $50 \mathrm{~g} \mathrm{~kg}^{-1}$ linseed flour, $30 \mathrm{~g} \mathrm{~kg}^{-1}$ cashew nut, Brazil nut and raisins, and $20 \mathrm{~g} \mathrm{~kg}^{-1}$ sunflower seeds. The binder phase was heated with stirring until the measured soluble sugar content reached $85-89^{\circ}$ Brix, measured using a digital refractometer (Leica Microsystems Inc. USA). The phases were mixed and dried in a conventional oven at $200{ }^{\circ} \mathrm{C}$ for $30 \mathrm{~min}$. The formulation was prepared in three replicates.

\subsection{Analysis}

The gluten fraction in the final product was determined using a commercial ELISA kit (enzyme-linked immunosorbent assay)-R5 Ridascreen ${ }^{\oplus}$ Gliadin kit (R-Biopharm, Germany). The gluten fractions were extracted with a $60 \%(\mathrm{v} / \mathrm{v})$ ethanol solution and reagent cocktail ${ }^{\circledast}$.

The proximate composition analyses (moisture, ash, crude protein, lipids, and carbohydrates by difference), crude energy (direct and indirect methods), gluten test, fatty acids, minerals ( $\mathrm{Ca}, \mathrm{Cu}, \mathrm{Fe}, \mathrm{Mg}, \mathrm{Mn}$, and $\mathrm{Zn}$ ), fatty acid rates, and Dietary Reference Intake were determined after processing.

Moisture, ash, and crude protein contents were determined according to Cunniff (1998) using factor 5.85 (Palombini et al., 2013) to convert the percentage of nitrogen into crude protein content. The total lipids were determined according to Bligh \& Dyer (1959). The total carbohydrate fraction was calculated by difference (Faithfull, 2002).

The caloric value was determined through indirect (calculation) (Holands et al., 1994) and direct (instrumental) calorimetry. For the instrumental method application, the samples were milled and dried at $105^{\circ} \mathrm{C}$ for $4 \mathrm{~h}$. Crude energy was determined using a 1261 Automatic Isoperibol (Parr, USA) oxygen bomb calorimeter. The results were obtained in cal g-1 of food and converted to Joules $(1 \mathrm{cal}=4.1868 \mathrm{~J})$ and expressed in $\mathrm{kJ} \mathrm{kg}^{-1}$ of product.

In order to determine the fatty acid composition, the lipids were converted into fatty acid methyl esters (FAME) and methylated, according to Hartman \& Lago (1973). The FAME were separated in a CP-3380 gas chromatograph (Varian, USA) fitted with a flame ionisation detector following the conditions used by Souza et al. (2013).

The retention times were compared to those of standard methyl esters (Sigma, USA). The fatty acids were identified using tricosanoic acid methyl ester (Sigma, USA) as an internal standard, as described by Joseph \& Ackman (1992). The peak areas were determined using the Star 5.0 software (Varian, USA), and the concentrations were expressed as $\mathrm{g} \mathrm{kg}^{-1}$ of food.

In the mineral composition analysis, the samples were digested by the dry method (Association of Official Anaytical Chemists, 1995), and $\mathrm{Ca}, \mathrm{Cu}, \mathrm{Fe}, \mathrm{Mg}, \mathrm{Mn}$, and $\mathrm{Zn}$ were quantified in an atomic absorption spectrophotometer AA240FS (Varian, USA) as mg of mineral per kg of product using standard solutions and analytical curves.

A better approach to the nutritional evaluation of fat is the use of indices based on the functional effects of the fatty acid composition. These indices are determined based on the atherogenicity index (AI) and the thrombogenicity index (TI), according to Ulbricht \& Southgate (1991), as well as the hypocholesterolemic/hypercholesterolemic fatty acid ratio $(\mathrm{HH})$, which is determined according to Santos-Silva et al. (2002). The Dietary Reference Intake (DRI) is a percent estimate of the daily nutrient requirements per age and gender established by the Institute of Medicine $(2001,2011)$ for individuals aged over 12 months. The DRI of $\mathrm{Ca}, \mathrm{Cu}, \mathrm{Fe}, \mathrm{Mg}, \mathrm{Mn}$, and $\mathrm{Zn}$ were determined as the average amount in 30 -g portions, as proposed by Brazil (2003) for cereal bars.

\section{Sensory, instrumental, and microbiological analyses during storage}

Sensory, instrumental, and microbiological analyses were performed in the granola after $0,21,42,63,84,105,126$, and 147 days of storage (day 0 was not exposed to storage conditions - it was considered the control). The product was packed in metallized polyester/polyethylene films and stored at a temperature of $30 \pm 2{ }^{\circ} \mathrm{C}$ with a relative humidity of $80 \pm 5 \%$.

A group of 30 untrained volunteer panellists and consumers of the product developed participated in the sensory analysis, which consisted of acceptance testing. The same group of tasters evaluated the granola formulated for 147 days of storage. The sample consisted of $20 \mathrm{~g}$ of granola. In the acceptance test, appearance, flavour, texture, crispness, and overall acceptance of the food bar were assessed using a nine-point hedonic scale $(1=$ extremely dislike to $9=$ extremely like). The index of acceptability (IA) of the product was calculated as (global aspect grade $\mathrm{x}$ 100\%) / 9, where nine was the maximum score in the hedonic scale. The lowest IA value for the product to be considered well accepted by the consumers was 70\% (Lawless \& Heymann, 2010). The evaluation was performed by verifying the acceptability (lower or significantly lower) of the bars stored in comparison to the bar control sample (day 0). The minimum acceptable score was 5 (American Society for Testing and Materials, 2011), which corresponds to the term 'neither liked nor disliked'. 


\section{Instrumental analysis}

Water activity was analysed using AquaLab 4TE (Decagon, USA) at $25{ }^{\circ} \mathrm{C}$ with an infrared detector. The mechanical properties of granola were obtained using a TA HD Plus (Stable, United Kingdom) universal texturometer with a $5.00 \mathrm{~kg}$ load cell and a $35.00 \mathrm{~mm}$ diameter acrylic cylinder. A compression speed of $0.80 \mathrm{~mm} \mathrm{~s}^{-1}$ was applied until $50 \%$ of the initial sample height was reached. This analysis was performed in quintuplicate. Parameters associated with texture, force, and deformation were obtained from the curve of maximum force peak versus height and expressed as hardness.

\section{Microbiological characterisation}

Food safety and product contamination were assessed after processing according to Brazil (2001) by evaluating Bacillus cereus, thermotolerant coliforms, and Salmonella sp., as proposed by Vanderzant \& Splittstoesser (1992). The microbiological analyses were performed before the sensory analyses in the previously established periods of time.

\subsection{Ethical aspects}

The sensory evaluation performed in this study was approved by the Standing Committee on Ethics in Research Involving Human Beings of Maringá State University, CAAE File No. 0433.0.093.000-10. All panellists provided a free and informed consent prior to their participation in the sensory analysis.

\subsection{Statistical and multivariate analyses}

Physicochemical, crude energy (directly and indirectly methods), fatty acid composition, and mineral analyses were carried out in triplicate. The results of sensory attributes (appearance, flavour, texture, crispness, and overall acceptance), water activity, and hardness were submitted to analysis of variance (ANOVA), and the groups were compared using Tukey's post hoc test; Student's t-test was used to compare the direct and indirect calorimetric measurements. Simple linear regression models were estimated individually for each parameter studied: appearance, flavour, texture, crispness, overall acceptance, water activity, and hardness as a function of storage time (days), according to Equation 1.

$\mathrm{Y}=\mathrm{a}+\mathrm{b} * \mathrm{X}_{1}$

Y: parameter, a: intercept, b: constant; $\mathrm{X}_{1}$ : regression coefficient (time).

PCA was used to analyze the sensory attributes, water activity, and hardness. The averages were autoscaled using the NIPALS algorithm. The statistical software SAS, version 7.0, was used with a $5 \%(\mathrm{p}<0.05)$ significance level for rejection of the null hypothesis.

\section{Results and discussion}

\subsection{Physicochemical characterisation and sensory aspects}

Gluten fractions were not detected by the ELISA kit in the gluten-free granola formulation, corroborating studies that have shown the absence of gluten in other varieties of the same species of grains used in the present study (Alvarez-Jubete et al., 2010).

Generally, gluten-free products have high carbohydrate concentration and low protein content. In the present study, total carbohydrates and crude protein were $688.99 \pm 4.12$ and $97.49 \pm 2.12 \mathrm{~g} \mathrm{~kg}^{-1}$, respectively. Segura \& Rosell (2011) found products with up to $92 \%$ carbohydrates. According to Enriquez et al. (2003), a higher percentage of pseudo-cereals in the food formulation is directly associated with higher protein content. The granola developed in the present study is a promising product for celiac disease patients due to its reduced carbohydrate and increased protein contents. This granola may be considered a source of protein because, according to Brazil (1998), it provides 10\% of the DRI (Daily Recommended Intake) for adults $\left(50 \mathrm{~g} \mathrm{day}^{-1}\right)$ in $100 \mathrm{~g}$ of product.

According to Gutiérrez et al. (2010), linseed has a mineral content of $2.66 \%$, while pseudo-cereals have approximately $3 \%$ (Palombini et al., 2013), which contributed to the high mineral content of the product developed. The granola formulation had $74.91 \pm 1.75,15.89 \pm 0.52$ and $122.72 \pm 3.02 \mathrm{~g} \mathrm{~kg}^{-1}$ of moisture, ash, and total lipids, respectively. The proximal composition and percent energy were similar to those found in a cereal bar in a study by Freitas \& Moretti (2006), with 10.71, 2.20, 15.31, 5.64 , and $60.97 \%$ moisture, ash, crude protein, total lipids, and carbohydrates, respectively. The direct $\left(17722.30 \pm 0.00 \mathrm{~kJ} \mathrm{~kg}^{-1}\right)$ and indirect $\left(17795.57 \pm 7.80 \mathrm{~kJ} \mathrm{~kg}^{-1}\right)$ methods were different ( $\mathrm{p}$ $<0.05$ ) according to Student's t-test; the indirect method does not measure the total energy content of other compounds in this product and therefore it can lead to bigger analytical errors.

The values of fatty acid (FA) composition of granola were $42.62 \pm 0.42,37.57 \pm 0.69$, and $14.52 \pm 0.46 \mathrm{~g} \mathrm{FA} \mathrm{kg}^{-1}$ of food for oleic acid, linoleic, and alpha-linolenic acid, respectively. The classes of FA and their role in the proper functioning of the body may be assessed by the use of nutritional indices (SantosSilva et al., 2002; Institute of Medicine, 2001) and their ratios (Harwood et al., 2007; Simopoulos, 2011). The atherogenicity index $(\mathrm{AI})$ was $0.13 \pm 0.01$, and the thrombogenicity index (TI) was $0.21 \pm 0.01$. These indices associate the presence of saturated fatty acids (SFA) such as lauric (12:0, not found), myristic $\left(14: 0,0.20 \pm 0.02 \mathrm{~g} \mathrm{FA} \mathrm{kg}^{-1}\right)$, palmitic $(16: 0,11.16 \pm 0.13$ $\left.\mathrm{g} \mathrm{FA} \mathrm{kg}^{-1}\right)$, and stearic $\left(18: 0,6.29 \pm 0.17 \mathrm{~g} \mathrm{FA} \mathrm{kg}^{-1}\right)$ acids to an increased incidence of coronary heart disease, when compared to monounsaturated fatty acids, especially oleic acid (18:1 n-9) and the series of omega 3 and 6 fatty acids. Ulbricht \& Southgate (1991) found similar values of AI and TI in dairy products and margarines containing polyunsaturated fatty acids (PUFA), respectively, and emphasised the direct relationship between a lower ratio of fatty acids and reduced risk of coronary heart disease. The major HH (8.34 \pm 0.04$)$ and PUFA:SFA $(2.82 \pm 0.04)$ ratios are important due to their hypocholesterolemic effect; the prevalence of polyunsaturated fatty acids is related 
to a lowered risk of cardiovascular disease (Ratnayake \& Galli, 2009). According to the Institute of Medicine (2002), saturated fatty acids should be avoided in a balanced diet. The presence of PUFA is recommended since high intake of SFA is associated with an increased risk of cardiovascular diseases (Harwood et al., 2007). According to Simopoulos (2011), high intake of lipids, trans fatty acids, and an unbalanced n-6:n-3 ratio are related to a higher frequency of myocardial infarction, hypercholesterolemia, increased low density lipoprotein (LDL) cholesterol and blood pressure, atheroma, lipid disorders, and others. The n-6:n-3 ratio of the granola developed was 2.59:1, which is close to the ideal value of 1:1 (Simopoulos, 2011).

The major mineral component found was $\mathrm{Cu}$ (Table 1). Its presence in the diet contributes to increased bioavailability and absorption of $\mathrm{Mg}, \mathrm{Mn}$, and $\mathrm{Zn}$, which are essential for the maintenance of biological systems because they participate as cofactors in metabolic reactions (Hathcock, 2004).

Table 1 shows the nutritional contribution (Institute of Medicine, 2001, 2004) of the granola formulation for different age groups, based on the value per portion established by Brazil (2003). The intake of trace minerals due to the consumption of the granola developed reached values 10\% higher than the DRI level. Cu contributed with almost twice the DRI level, an amount that is not toxic since it is lower than the tolerable daily intake level (Institute of Medicine, 2001, 2004).

Due to the high contents of $\mathrm{Cu}, \mathrm{Fe}, \mathrm{Mg}, \mathrm{Mn}$, and $\mathrm{Zn}$ (over $15 \%$ DRI of each mineral per portion) (Brazil, 1998), this granola formulation is a good source of these minerals. The consumption of foods rich in minerals may reduce the risk of

Table 1. Minerals (Ca, Cu, Fe, Mg, Mn, and Zn) contents in 30-g granola portions as percentages of Dietary Reference Intake (DRI) per age and gender.

\begin{tabular}{|c|c|c|c|c|c|c|}
\hline \multirow{2}{*}{$\begin{array}{c}\text { Mineral } \\
\left(\mathrm{mg} \mathrm{Kg}^{-1} \text { of sample }\right)\end{array}$} & $\mathrm{Ca}$ & $\mathrm{Cu}$ & $\mathrm{Fe}$ & $\mathrm{Mg}$ & $\mathrm{Mn}$ & $\mathrm{Zn}$ \\
\hline & 2144.38 & 26.02 & 86.66 & 2554.04 & 34.73 & 78.76 \\
\hline Age group (years) & \pm 83.75 & \pm 3.03 & \pm 0.42 & \pm 31.90 & \pm 0.13 & \pm 2.83 \\
\hline \multicolumn{7}{|l|}{ Children } \\
\hline 01-03 & 9.19 & 229.41 & 37.16 & 95.62 & 86.75 & 78.80 \\
\hline 04-08 & 6.43 & 177.27 & 26.01 & 58.94 & 69.40 & 47.28 \\
\hline \multicolumn{7}{|l|}{ Men } \\
\hline 09-13 & 4.95 & 111.43 & 32.51 & 31.93 & 54.79 & 29.55 \\
\hline $14-18$ & 4.95 & 87.40 & 23.65 & 18.69 & 47.32 & 21.49 \\
\hline $19-50$ & 6.43 & 86.67 & 32.51 & 18.24 & 45.26 & 21.49 \\
\hline $51-70$ & 6.43 & 68.67 & 32.51 & 18.24 & 45.26 & 21.49 \\
\hline$>70$ & 5.36 & 68.67 & 32.51 & 18.24 & 45.26 & 21.49 \\
\hline \multicolumn{7}{|l|}{ Women } \\
\hline 09-13 & 4.95 & 88.29 & 32.51 & 31.93 & 65.06 & 29.55 \\
\hline $14-18$ & 4.95 & 69.44 & 17.34 & 21.28 & 65.06 & 26.27 \\
\hline $19-50$ & 6.43 & 68.67 & 14.45 & 23.94 & 57.83 & 29.55 \\
\hline$>50$ & 5.36 & 68.67 & 32.51 & 23.94 & 57.83 & 29.55 \\
\hline \multicolumn{7}{|l|}{ Pregnant } \\
\hline 14-18 & 4.95 & 78.00 & 9.63 & 19.16 & 37.05 & 19.70 \\
\hline 19-50 & 6.43 & 78.00 & 9.63 & 21.28 & 37.05 & 21.49 \\
\hline \multicolumn{7}{|l|}{ Lactating } \\
\hline 14-18 & 4.95 & 60.00 & 26.01 & 21.28 & 28.50 & 18.18 \\
\hline $19-50$ & 6.43 & 60.00 & 28.90 & 23.94 & 28.50 & 19.70 \\
\hline
\end{tabular}

Table 2. Means and standard deviations of sensory attributes, water activity and hardness of granola.

\begin{tabular}{cccccccc}
\hline \multirow{2}{*}{ Days } & \multicolumn{7}{c}{ Parameters } \\
\cline { 2 - 7 } & Appearance & Flavor & Texture & Crispness & ${ }^{\mathrm{a}}$ OA & $\mathrm{A}_{\mathrm{w}}$ \\
\hline 0 & $8.53^{\mathrm{a}} \pm 0.94$ & $8.40^{\mathrm{a}} \pm 0.56$ & $8.30^{\mathrm{a}} \pm 0.79$ & $8.43^{\mathrm{a}} \pm 0.82$ & $8.57^{\mathrm{a}} \pm 0.57$ & $0.46^{\mathrm{a}} \pm 0.01$ & $19.69^{\mathrm{a}} \pm 0.04$ \\
21 & $8.00^{\mathrm{ab}} \pm 0.69$ & $7.97^{\mathrm{ab}} \pm 0.72$ & $7.90^{\mathrm{ab}} \pm 0.66$ & $7.93^{\mathrm{ab}} \pm 0.58$ & $8.10^{\mathrm{ab}} \pm 0.71$ & $0.47^{\mathrm{a}} \pm 0.00$ & $19.46^{\mathrm{b}} \pm 0.06$ \\
42 & $7.80^{\mathrm{ab}} \pm 0.96$ & $7.83^{\mathrm{ab}} \pm 1.44$ & $7.87^{\mathrm{ab}} \pm 1.22$ & $7.90^{\mathrm{ab}} \pm 0.92$ & $7.93^{\mathrm{ab}} \pm 1.08$ & $0.47^{\mathrm{a}} \pm 0.00$ & $19.00^{\mathrm{c}} \pm 0.02$ \\
63 & $7.70^{\mathrm{ab}} \pm 0.99$ & $7.73^{\mathrm{ab}} \pm 1.11$ & $7.67^{\mathrm{ab}} \pm 1.09$ & $7.93^{\mathrm{ab}} \pm 0.91$ & $7.87^{\mathrm{ab}} \pm 1.14$ & $0.47^{\mathrm{a}} \pm 0.00$ & $18.86^{\mathrm{d}} \pm 0.07$ \\
84 & $7.63^{\mathrm{b}} \pm 1.07$ & $7.60^{\mathrm{ab}} \pm 1.19$ & $7.50^{\mathrm{ab}} \pm 0.97$ & $7.77^{\mathrm{ab}} \pm 1.07$ & $7.70^{\mathrm{ab}} \pm 1.18$ & $0.47^{\mathrm{a}} \pm 0.01$ & $18.24^{\mathrm{d}} \pm 0.03$ \\
105 & $7.60^{\mathrm{b}} \pm 1.30$ & $7.53^{\mathrm{ab}} \pm 1.38$ & $7.50^{\mathrm{ab}} \pm 1.28$ & $7.67^{\mathrm{ab}} \pm 1.18$ & $7.57^{\mathrm{b}} \pm 1.33$ & $0.48^{\mathrm{a}} \pm 0.01$ & $17.80^{\mathrm{e}} \pm 0.04$ \\
126 & $7.30^{\mathrm{b}} \pm 1.26$ & $7.40^{\mathrm{b}} \pm 1.40$ & $7.33^{\mathrm{b}} \pm 1.27$ & $7.47^{\mathrm{b}} \pm 1.17$ & $7.50^{\mathrm{b}} \pm 1.28$ & $0.48^{\mathrm{a}} \pm 0.02$ & $17.80^{\mathrm{f}} \pm 0.06$ \\
147 & $7.20^{\mathrm{b}} \pm 1.24$ & $7.47^{\mathrm{b}} \pm 1.22$ & $7.53^{\mathrm{ab}} \pm 1.22$ & $7.63^{\mathrm{ab}} \pm 1.43$ & $7.23^{\mathrm{b}} \pm 1.61$ & $0.48^{\mathrm{a}} \pm 0.01$ & $17.43^{\mathrm{g}} \pm 0.01$ \\
\hline
\end{tabular}

${ }^{1}$ OA: Overall acceptance. Means followed by the same letters in columns do not differ by Tukey's test $(\mathrm{p}<0.05)$. A : water activity. 
coronary heart disease, anaemia, osteoporosis, and prostate cancer by boosting the immune system (Hathcock, 2004).

\subsection{Sensory, instrumental, and microbiological characterisation during storage}

The sensory attributes evaluated in the granola (Table 2) showed significant differences $(p<0.05)$ over the 147 days of storage. Product acceptance was satisfactory since none of the attributes had score below 5, i.e. 'neither like nor dislike' (American Society for Testing and Materials, 2011). There was a decrease in the acceptance rate with storage time, but this was not lower than $70 \%$ and is also considered acceptable (Dutcosky et al., 2006). Initially, the panellists scored granola as 'like very much' in all parameters studied. After 21 days of storage, the scores were close to 7 ('like moderately'), and this was maintained until the end of the experiment. These results indicate that the changes (microbiological, chemical, physical, and biochemical) that occurred in the granola formulated during storage at $30^{\circ} \mathrm{C}$ were not enough to make the product unacceptable to consumers.

Water activity readings $\left(\mathrm{A}_{\mathrm{w}}\right)$ varied very little $(0.02)$ throughout the experiment (Table 2), and there were no significant differences $(p<0.05)$. Despite the increase in $A_{w}$ the final content did not favour the proliferation of microorganisms since this value did not exceed 0.60 (Sun-Waterhouse et al., 2010).

The instrumental texture parameters showed a significant decrease during storage, and they were different in all the time periods analysed $(\mathrm{p}<0.05)$. Katz \& Labuza $(1981)$ observed that crunchy foods show changes in texture when there is a variation between 0.35 to 0.50 in $A_{w}$, and then they have a tendency to stability. The $\mathrm{A}_{\mathrm{w}}$ in the present study had a small variation (0.02) over the storage period of 147 days, but it was enough to decrease the instrumental hardness of the granola (Table 2). This decrease may have been due to chemical or physical reactions, such as melting or crystallisation, and transitions related to molecular mobility, such as glass transition (Loverday et al., 2009).

The granola formulation had low water activity, which contributed to microbial growth inhibition and the absence of Bacillus cereus, thermotolerant coliforms, and Salmonella sp. during storage under appropriate sanitary conditions (Brazil, 2001).

\subsection{Regression models and principal component analysis}

The simple linear regression models were highly significant ( $\mathrm{p}<0.05)$, and the estimated standard error was low for all parameters evaluated (Table 3). Figure 1 shows a decrease in the sensory attributes and instrumental hardness, while the water activity increased linearly. This decrease was significant $(p<0.05)$ and is an indicative of linear variations between the means of the parameters analysed and storage time. At 0, 63, and 105 days, there was variation of about $95 \%$ in appearance (Figure 1A), flavour (Figure 1B), and overall acceptance (Figure 1D). Similar results were found for hardness at the last two time periods evaluated (Figure 1G). According to Burgard \& Kuznicki (1990), coefficients of determination $\left(\mathrm{R}^{2}\right)$ values greater than 0.60 are considered very good when evaluating instrumental versus sensory data and/or as a function of time. In the present study, all $\mathrm{R}^{2}$ values were greater than 0.85 (Table 3). Analysing the Pearson correlation coefficients ( $r$ ) in all regression models, it was verified that the data were highly correlated, i.e. some parameters were directly proportional to the effects of depreciation (negative regression coefficients for the sensory attributes and hardness) and increased (positive regression coefficient of water activity) throughout the storage period (Table 3, Figure 1).

The NIPALS algorithm enabled us to select PC1, PC2, and PC 3 , which were significant $(\mathrm{p}<0.05)$ and explained $58.79 \%$ of the variance in the data. In Figure 2A (on PC1), a positive correlation was verified between all sensory attributes and hardness up to 63 days of storage. The analysis of PC2 (Figure 2A), shows a negative correlation between all sensory parameters and water activity after the $84^{\text {th }}$ day of storage, (Figure 2A). This effect was due to decreased hardness, with a consequent reduction in the sensory scores (Table 2). During the following time periods: $0-21,42-63$, and 84-126 days of storage, a positive correlation was observed between the appearance and overall acceptance through PC3 (Figure 2B). During these time periods, the product was stable with respect to these parameters.

\section{Conclusion}

The use of naturally gluten-free ingredients allowed the development of a granola formulation for celiac disease patients. Grains such as amaranth, quinoa, and linseed contributed to an increase in the protein, lipid, and mineral contents in the

Table 3. Linear regression models for the sensory attributes, water activity, and hardness of granola.

\begin{tabular}{|c|c|c|c|c|c|}
\hline Parameters & Equations & $\mathrm{R}^{2}$ & $\mathrm{R}$ & Standard error of estimate & $\mathrm{p}$ \\
\hline Appearance & $\mathrm{Y}=8.2833-0.0077^{\star} \mathrm{X}$ & 0.8926 & 0.9447 & 0.1338 & 0.0004 \\
\hline Flavor & $\mathrm{Y}=8.1744-0.00056^{*} \mathrm{X}$ & 0.8586 & 0.9267 & 0.1535 & 0.0009 \\
\hline Texture & $\mathrm{Y}=8.0950-0.0054 * \mathrm{X}$ & 0.7975 & 0.8930 & 0.1837 & 0.0028 \\
\hline Crispness & $\mathrm{Y}=8.2089-0.0050 * \mathrm{X}$ & 0.7828 & 0.8848 & 0.1902 & 0.0035 \\
\hline${ }^{1} \mathrm{OA}$ & $\mathrm{Y}=8.3747-0.0077^{\star} \mathrm{X}$ & 0.9364 & 0.9677 & 0.1029 & 0.0001 \\
\hline $\mathrm{A}_{\mathrm{w}}$ & $\mathrm{Y}=0.4608+0.0001 * \mathrm{X}$ & 0.9800 & 0.9603 & 0.0813 & 0.0000 \\
\hline Hardness & $\mathrm{Y}=19.7275-0.01657^{\star} \mathrm{X}$ & 0.9801 & 0.9900 & 0.0576 & 0.0000 \\
\hline
\end{tabular}

${ }^{1} \mathrm{OA}$ : Overall acceptance. $\mathrm{A}_{\mathrm{w}}$ : water activity. 

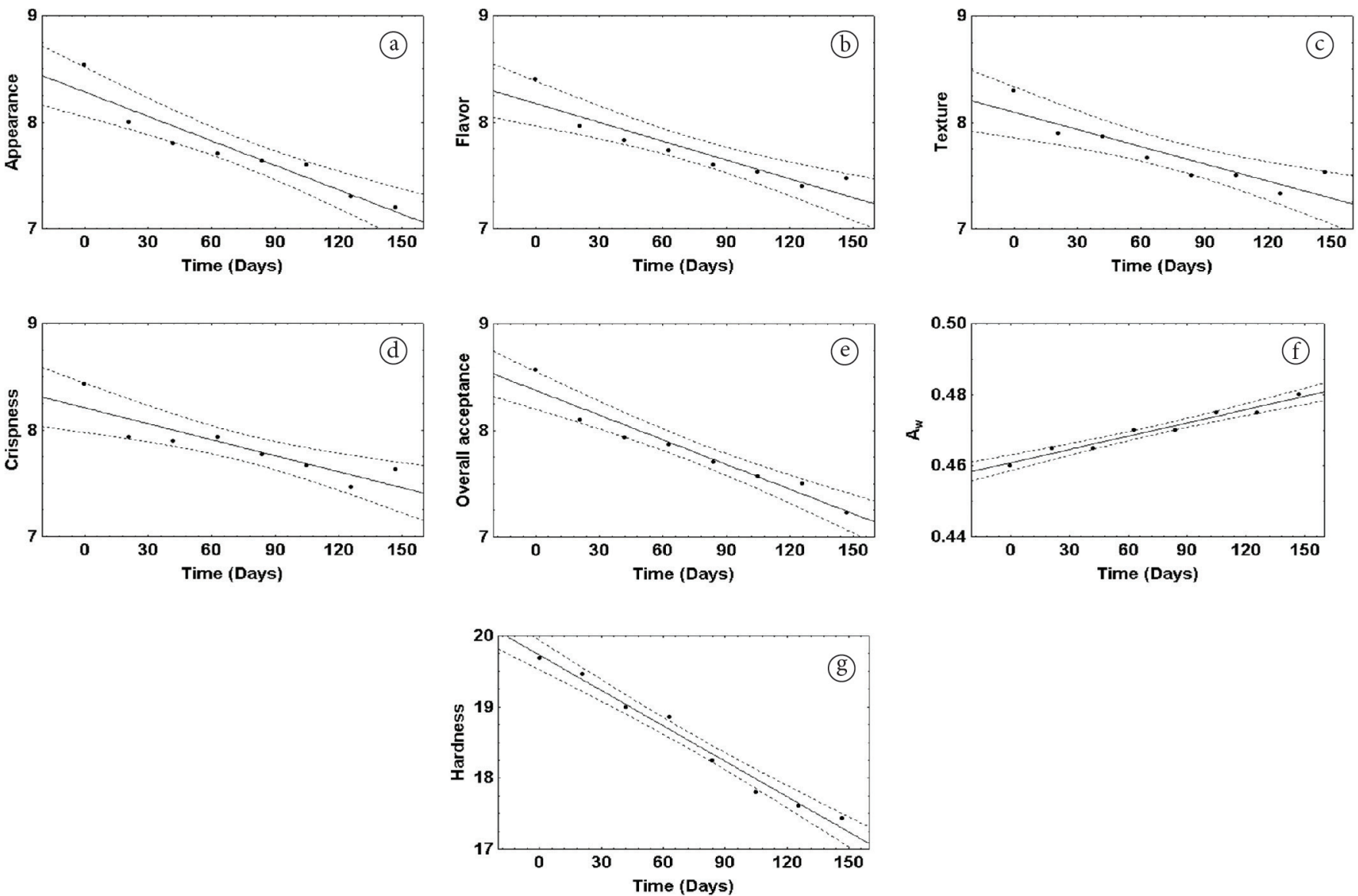

Figure 1. Linear regression models for the sensory attributes, water activity, and hardness of granola. $\mathrm{A}_{\mathrm{w}}$ : water activity.
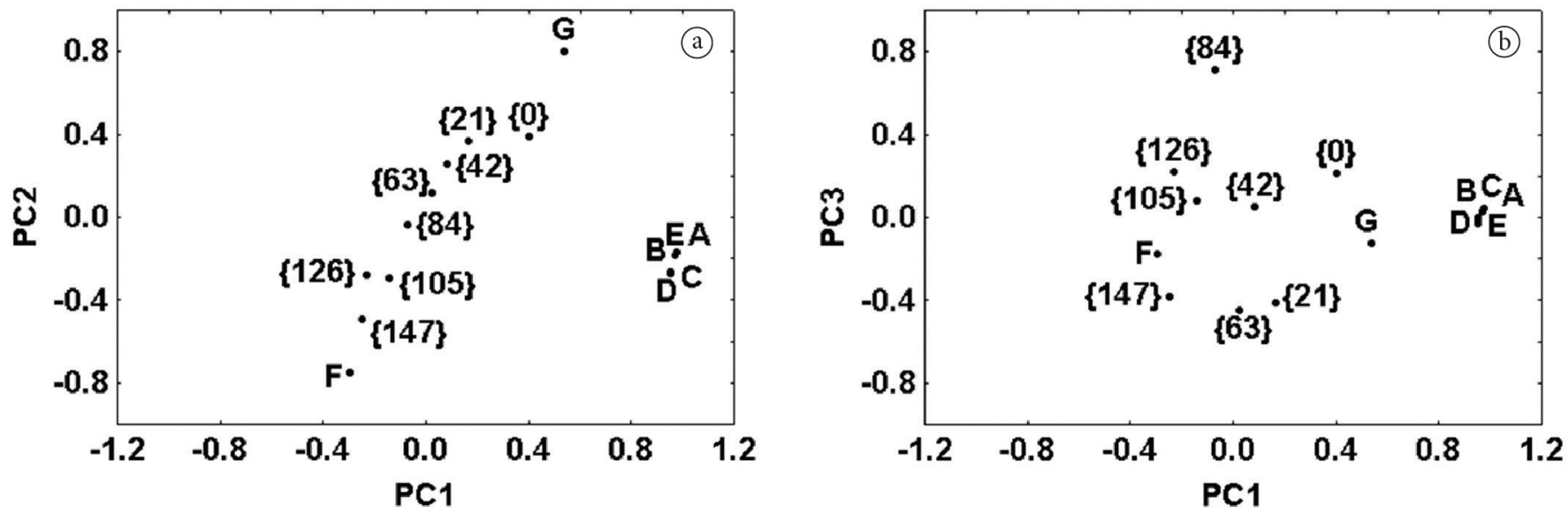

Figure 2. Principal component analysis of the parameters analysed for granola. A: Appearance; B: Flavor; C: Texture; D: Crispness; E: Overall acceptance; F: Water activity; G: Hardness.

product. The contents of $\mathrm{Cu}, \mathrm{Fe}, \mathrm{Mg}, \mathrm{Mn}$, and $\mathrm{Zn}$ were $15 \%$ higher than the DRI level. There were good hygienic and sanitary conditions during storage; microbial growth was probably inhibited by the low water activity. The sensory attributes scores ranged from 'like very much' to 'like slightly', and the regression models were highly fitted and correlated with the storage time.
It was possible to analyse the effect of the reduction in the sensory attributes and physical stabilisation of the product by the principal component analysis. The use of affective sensory tests of acceptance and instrumental analyses allied with statistical methods provided promising results in terms of the behaviour of stored granola. 


\section{References}

Alvarez-Jubete, L., Wijngaard, H., Arendt, E. K., \& Gallagher, E. (2010). Polyphenol composition and in vitro antioxidant activity of amaranth, quinoa buckwheat and wheat as affected by sprouting and baking. Food Chemistry, 119(2), 770-778. http://dx.doi. org/10.1016/j.foodchem.2009.07.032

American Society for Testing and Materials - ASTM. (2011). ASTM E2454 - 05: Standard guide for sensory evaluation methods to determine the sensory shelf life of consumer products. West Conshohocken.

Association of Official Anaytical Chemists - AOAC. (1995). Official Methods of Analysis of the Association of Official Anaytical Chemists. Arlington: AOAC.

Bligh, E. G., \& Dyer, W. J. (1959). A rapid method of total lipid extraction and purification. Canadian Journal of Biochemistry and Physiology, 37(8), 911-917. http://dx.doi.org/10.1139/o59-099

Brazil. (1998). Portaria n²7, 13 de janeiro de 1998. Regulamento técnico referente à informação nutricional complementar. Diário Oficial da República Federativa do Brasil.

Brazil. (2001). Resolução - RDC nº12, 2 janeiro de 2001. Regulamento técnico sobre padrões microbiológicos para alimentos. Diário Oficial da República Federativa do Brasil.

Brazil. (2003). Resolução - RDC n³59, 23 de dezembro de 2003. Regulamento técnico de porções de alimentos embalados para fins de rotulagem nutricional. Diário Oficial da República Federativa do Brasil.

Burgard, D. R., \& Kuznicki, J. T. (1990). Chemometrics: chemical and sensory data. Boston: Taylon \& Fancis, CRC Press. 208 p.

Correia, P. R. M., \& Ferreira, M. C. (2007). Exploring chemometrical procedures for evaluating analytical data. Química Nova, 30(2), 481-487. http://dx.doi.org/10.1590/S0100-40422007000200042

Cunniff, P. A. (1998). Official methods of analysis of AOAC international. Arlington: Association of Official Analytical Chemists. CD-ROM.

Dutcosky, S. D., Grossmann, M. V. E., Silva, R. S. F., \& Welsch, A. K. (2006). Combined sensory optimization of a prebiotic cereal product using multicomponent mixture experiments. Food Chemistry, 98(4), 630-638. http://dx.doi.org/10.1016/j.foodchem.2005.06.029

Enriquez, N., Peltzer, M., Raimundi, A., Tose, V., \& Pollio, M. L. (2003). Characterization of wheat and quinoa flour blends in relation to their breadmaking quality. Journal of the Argentine Chemical Society, 91(4-6), 47-54.

Faithfull, N. T. (2002). Methods in agricultural chemical analysis: a practical handbook. New York: Cabi Publishing. http://dx.doi. org/10.1079/9780851996080.0000

Fasano, A., Araya, M., Bhatnagar, S., Cameron, D., Catassi, C., Dirks, M., Mearin, M. L., Ortigosa, L., \& Philips, A. (2008). Federation of international societies of pediatric gastroenterology, hepatology, and nutrition consensus report on celiac disease. Journal of Pediatric Gastroenterology and Nutrition, 47(2), 214-219. http://dx.doi. org/10.1097/MPG.0b013e318181afed

Freitas, D. G. C., \& Moretti, R. H. (2006). Characterization and sensorial evaluation of functional cereal bar. Food Science and Technology, 26(1), 318-324.

Giménez, A., Ares, F., \& Ares, G. (2012). Sensory shelf-life estimation: A review of current methodological approaches. Food Research International, 49(1), 311-325. http://dx.doi.org/10.1016/j. foodres.2012.07.008
Gutiérrez, C., Rubilar, M., Jara, C., Verdugo, M., Sineiro, J., \& Shene, C. (2010). Flaxseed and flaxseed cake as a source of compounds for food industry. Journal of Plant Nutrition and Soil Science, 10(4), 454-463. http://dx.doi.org/10.4067/S0718-95162010000200006

Hartman, L., \& Lago, R. C. A. (1973). Rapid preparation of fatty acid methyl esters from lipids. Laboratory Practice, 22(6), 475-477.

Harwood, J. L., Evans, M., Ramji, D. P., Murphy, D. J., \& Dodds, P. F. (2007). Medical and agricultural aspects of lipids. In: J. L. Harwood, F. D. Gunstone \& A. J. Dijkstra. The lipid handbook (cap. 11, pp. 703756). New York: CRC Press.

Hathcock, J. N. (2004). Vitamin and mineral safety. 2nd ed. Washington: Council for responsible nutrition.

Holands, B., Welch, A. A., Unwin, I. D., Buss, D. H., Paul, A. A., \& Southgate, D. A. T. (1994). MacCance and winddowson's: The composition of foods. Cambridge: The Royal Society of Chemistry and Ministry of Agriculture, Fisheries and Food.

Institute of Medicine. (2001). Dietary Reference Intakes for vitamin A, vitamin $K$, arsenic, boron, chromium, copper, iodine, manganese, molybdenum, nickel, silicon, vanadium, and zinc. Washington: National Academy Press.

Institute of Medicine. (2002). Dietary Reference Intakes for energy, carbohydrate, fiber, fat, fatty acids, cholesterol, protein, and amino acids. Washington: National Academy Press.

Institute of Medicine. (2011). Dietary Reference Intakes for calcium and vitamin D. Washington: National Academy Press.

Joseph, J. D., \& Ackman, R. (1992). Capillary column gas chromatographic method for analysis of encapsulated fish oils and fish oil ethyl esters: collaborative study. Journal of the American Oil Chemists' Society, 75(3), 488-506.

Katz, E. E., \& Labuza, T. P. (1981). Effect of water activity on the sensory crispness and mechanical deformation of snack food products. Journal of Food Science, 46(2), 403-409. http://dx.doi. org/10.1111/j.1365-2621.1981.tb04871.x

Lawless, H. T., \& Heymann, H. (2010). Sensory Evaluation of Food: Principles and practices. 2. ed. Berlin: Springer. 619 p. http://dx.doi. org/10.1007/978-1-4419-6488-5

Loverday, S. M., Hindmarsh, J. P., Creamer, L. K., \& Singh, H. (2009). Physicochemical changes in a model protein bar during storage. Food Research International, 42(7), 798-806. http://dx.doi. org/10.1016/j.foodres.2009.03.002

Palombini, S. V., Claus, T., Maryama, S. A., Gohara, A. K., Souza, A. H. P., Souza, N. E., Visentainer, J. V., Gomes, S. T. M., \& Matsushita M. (2013). Evaluation of nutritional compounds in new amaranth and quinoa cultivars. Food Science and Technology, 33(2), 339-344. http://dx.doi.org/10.1590/S0101-20612013005000051

Ratnayake, WM., \& Galli, C. (2009). Fat and fatty acid terminology, methods of analysis and fat digestion and metabolism: A background review paper. Annals of Nutrition and Metabolism, 55(1-3), 8-43. http://dx.doi.org/10.1159/000228994

Ryan, E., Galvin, K., O’Connor, T. P., \& Maguire, A. R. (2007). Phytosterol, squalene, tocopherol content and fatty acid profile of selected seeds, grains, and legumes. Plant Foods for Human Nutrition, 62(3), 85-91. http://dx.doi.org/10.1007/s11130-0070046-8

Santos-Silva, J., Bessa, R. J. B., \& Santos-Silva, F. (2002). Effect of genotype, feeding system and slaughter weigt on the quality of light lambs. II. Fatty acid composition of meat. Livestock Production 
Science, 77(2-3), 187-194. http://dx.doi.org/10.1016/S03016226(02)00059-3

Segura, M. E. M., \& Rosell, C. M. (2011). Chemical composition and starch digestibility of different gluten-free breads. Plant Foods for Human Nutrition, 66(3), 224-230. http://dx.doi.org/10.1007/ s11130-011-0244-2

Simopoulos, A. (2011). Evolutionary aspects of diet: the omega-6/ omega-3 ratio and the brain. Molecular Neurobiology, 44(2), 203215. http://dx.doi.org/10.1007/s12035-010-8162-0

Souza, A. H. P., Gohara, A. K., Rodrigues, A. C., Souza, N. E., Visentainer, J. V.,\& Matsushita, M. (2013). Sacha inchi as pontencial source of essencial fatty acids and tocopherols: multivariate study of nut and shell. Acta Scientiarum. Technology, 35(4), 757-763. http:// dx.doi.org/10.4025/actascitechnol.v35i4.19193

Spehar, C. R., Santos, R. L. B., \& Quinoa, B. R. S. (2002). Piabiru: alternative for diversification of cropping systems. Pesquisa Agropecuária Brasileira, 37(6), 889-893.
Spehar, C. R., Teixeira, D. L., Cabezas, W. A. R. L., \& Erasmo, E. A. L. (2003). Amaranth BRS Alegria: alternative for diversification of croppings systems. Pesquisa Agropecuária Brasileira, 38(5), 659-663. http://dx.doi.org/10.1590/S0100-204X2003000500015

Sun-Waterhouse, D., Teoh, A., Massarotto, C., Wibisono, R., \& Wadhwa, S. (2010). Comparative analysis of fruit-based functional snack bars. Food Chemistry, 119(4), 1369-1379. http://dx.doi. org/10.1016/j.foodchem.2009.09.016

Ulbricht, T. L. V., \& Southgate, D. A. T. (1991). Coronary heart disease: seven dietary factors. Lancet, 338(8773), 985-992. http://dx.doi. org/10.1016/0140-6736(91)91846-M

Vanderzant, C., \& Splittstoesser, D. F. (1992). Compendium of Methods for the Microbiological Examination of Foods. Washington: Edwards Brothers Ann Arbor. 1219 p. 